\title{
Chemical composition of human and canine fascia lata
}

\section{Krzysztof Maksymowicz¹, Krzysztof Marycz², Sylwia Szotek³, Krzysztof Kaliński², Ewa Serwa², Robert Łukomski ${ }^{4}$ and Joanna Czogała ${ }^{\infty}$}

1Department of Forensic Medicine, Faculty of Medicine, Wrocław Medical University, Wrocław, Poland; 2Electron Microscopy Laboratory, Department of Biology and Animal Breeding, Wrocław University of Environmental and Life Sciences, Wrocław, Poland; ${ }^{3}$ Division of Biomedical Engineering and Experimental Mechanics, Faculty of Mechanical Engineering, Wrocław University of Technology, Wrocław, Poland; ${ }^{4}$ nnstitute of Electrical Power Engineering, Faculty of Electrical Engineering, Wrocław University of Technology, Wrocław, Poland; 5 Veterinary Clinic Brynów, Katowice, Poland

The fascial system is an integral part of the musculoskeletal system. It is a three-dimensional network of connective tissue spreading ubiquitously throughout the body, surrounding muscles, bones, internal organs, nerves, vessels, and other structures. The basic biophysical properties of the fascial system are determined by its structure and chemical composition. This study aimed to determine the elemental composition of pathologically unchanged fascia lata of the thigh, collected during autopsies on humans and dogs. The wide spectrum of elements analysed included both macro and micro elements. The analyses were conducted using scanning electron microscopy with X-ray microanalysis (SEMEDS). Concentrations of the following macro and micro elements were dermined: $\mathrm{C}, \mathrm{N}, \mathrm{O}, \mathrm{Na}, \mathrm{Mg}, \mathrm{Al}, \mathrm{Si}, \mathrm{P}, \mathrm{S}$, $\mathrm{Cl}, \mathrm{K}, \mathrm{Ca}, \mathrm{Ti}, \mathrm{Fe} \mathrm{Co}, \mathrm{Ni}, \mathrm{Cu}$, and $\mathrm{Zn}$. The obtained results showed significant differences between human and canine fascia lata regarding the content of most of the examined elements $(p<0.05)$, except for $\mathrm{N}$. These data may in future provide a starting point for the establishment of reference values for the content of various elements in normal fascial tissue and may also serve to verify the usefulness of experimental animal material as a substitute for human tissue.

Key words: fascia lata, elemental composition, SEM-EDS, human, dog

Received: 29 July, 2011; revised: 05 October, 2012; accepted: 14 November, 2012; available on-line: 19 November, 2012

\section{INTRODUCTION}

Fascia is a strong connective tissue structure formed by an ordered arrangement of collagen fibres playing mainly mechanical and protective functions in an organism. It is an element coordinating muscle motor units and connecting body joints, thus enabling harmonious movement of humans and animals (Chaudhry et al., 2007; Stecco et al., 2009). On the functional, morphological, and biochemical levels, disturbances in fascial structures may manifest themselves as a considerable limitation of mobility and often strong pain reactions. In spite of the significant contribution of the fascia to the functioning of the motor system in humans and animals, these structures are not yet satisfactorily understood, especially when compared to other elements of the broadly-defined musculoskeletal system (Samborski, 2006). In order to broaden the general knowledge of the fascial system, we decided to investigate the elemental composition of fascia lata.
Our basic knowledge of human and animal tissues and internal organs stems mainly from their anatomical, histological, and ultrastructural analyses. Based on this information, indirect conclusions may often be drawn on the metabolic status of the analysed structures. Despite the fact that this knowledge is very detailed, it is nonetheless incomplete since it does not take into consideration the chemical composition of the analysed objects or the relationship between such composition and the structure of the analysed body tissues.

Only few papers on the elemental composition of specific organs or tissues, have been published The same is the case for connective tissue structures, including fascia. The publications available point to a relatively constant mineral composition of the body of an adult human being regardless of age and sex (Brown, 1926; Robertson, 1961; Robertson, 1961; Kahler, 1976; Widdowson et al., 1995). This knowledge may be useful in determining the content of particular elements in normal tissues, including fascia. Deviations from the specified reference values would thus indicate a pathology. So far, information on the elemental composition of biological material originating from the patient has been often omitted in the diagnostic process (except for the routine biochemical analysis of blood).

The proper functioning of cells and tissues is to a considerable degree conditioned by mineral homeostasis. Even a small degree of disturbance of that homeostasis may potentially lead to the occurrence of functional, or even structural, abnormalities (Larsen et al., 1960; Sahin et al., 2001; Koźma et al., 2001). From the point of view of tissue physiology, proper levels of both macro (e.g., $\mathrm{Ca}, \mathrm{Mg}, \mathrm{Na}, \mathrm{K}$, and $\mathrm{Cl}$ ) and micro elements (e.g., Fe, Co, Cu, $\mathrm{Zn}$ ) are essential. The cations $\mathrm{Ca}^{2+}, \mathrm{Mg}^{2+}, \mathrm{Na}^{+}$, and $\mathrm{K}^{+}$play a key role in muscle contraction and thus also in the dynamics of the cooperating fascial system. The main anions playing a similar role are $\mathrm{Cl}^{-}$and $\mathrm{OH}^{-}$, which are the basic elements of efficiently functioning ionic canals. Among micro elements, $\mathrm{Zn}, \mathrm{Fe}$, and $\mathrm{Cu}$ are especially important for the proper functioning of fascial tissues

e-mail: joannaczogala@gmail.com

Abbreviations: $\mathrm{Al}$, aluminium; $\mathrm{C}$, carbon; $\mathrm{Ca}$, calcium; $\mathrm{Cl}$, chlorine; $\mathrm{Co}$, cobalt; $\mathrm{Cu}$, copper; Fe, iron; $\mathrm{K}$, potassium; $\mathrm{Mg}$, magnesium; $\mathrm{Na}$, sodium; $\mathrm{N}$, nitrogen; $\mathrm{Ni}$, nickel; $\mathrm{O}$, oxygen; $\mathrm{P}$, phosphorus; $\mathrm{S}$, sulphur; Si, silicon; Ti, titanium; Zn, zinc; wt.\%, weight percentage; SEM-EDS, scanning electron microscopy with X-ray microanalysis; U M-W, test U Mann-Whitney. 
because they influence synthesis and regeneration of collagen fibres - the main building components of the fascia (Becker et al., 1968; Tengrup et al., 1981).

The chemical characteristics of both organic and inorganic matter are analysed using, among other, optic crystallography, X-ray diffraction, and infrared spectroscopy (Byrne et al., 1989; Vanhoe et al., 1989; Krachler et al., 1998; Olszytńska-Janus et al., 2008, Olsztyńska-Janus et al., 2012; Guidotti et al., 2008; Sun et al., 2009). It can, therefore, be concluded that different methods give different kinds of information (Guidotti et al., 2008). Electron microscopy is currently a commonly used analytical technique in numerous scientific disciplines, including biological sciences. The application of scanning electron microscopy combined with X-ray microanalysis (SEM-EDS) as a research method seems to be an appropriate solution due to the small amount of material needed for the analysis, and also its relatively short duration. Both these features are especially desirable in the case of specimens of biological origin, particularly in the course of clinical diagnostic process, for example urinary stone analysis (Czogała et al., 2006; Kaliński et al., 2009).

The aim of the present study was a quantitative determination of the elemental composition of fascial tissues of humans and animals using scanning electron microscopy coupled with X-ray microanalysis. Also, the study mapped various elements on the surface of selected specimens. The chemical characteristics of pathologically unchanged fascial tissues may be applied in future as a database useful in medical and veterinary transplantology.
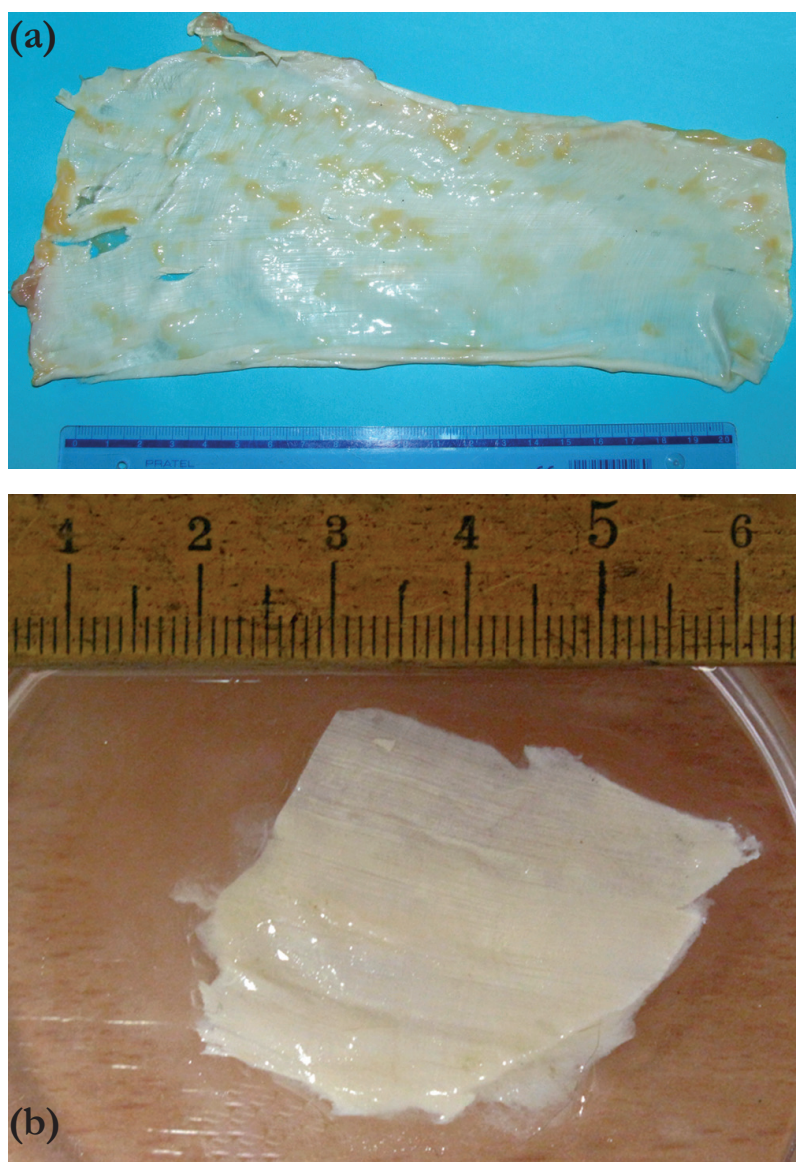

Figure 1. Images of sample specimens of fascia lata of the thigh collected from a human (a) and a dog (b), from which the material for elemental composition determination was collected.

\section{MATERIALS AND METHODS}

The study was conducted on pathologically unchanged fascia lata of the thigh, collected post-mortem from humans and dogs (Fig. 1). Ten human and seven animal specimens were examined in the Laboratory of Electron Microscopy at the Wroclaw University of Environmental and Life Sciences. At the beginning of the experiment, different specimens collected randomly from specific areas of the analysed tissue were checked in order to verify biochemical homogeneity of the material. Next, a $10 \times 15 \mathrm{~mm}$ fragment was collected from the central part of each specimen in order to conduct the elemental composition analysis.

The measurements were conducted using the technique of elemental analysis on the electron level with a Quantax 200 Esprit 1.8.2 EDS X-ray microanalysis device coupled with an EVO 15 LS scanning electron microscope. The examined material was fixed in $2.5 \%$ glutaraldehyde in phosphate buffer $(\mathrm{pH} 7.4)$ and then rinsed in $\mathrm{pH} 7.4$ phosphate buffer. Once prepared, such specimens were dehydrated in acetone-water series of gradually increasing concentration (from 30 to 100\%) and then dried convectionally at room temperature and glued on tables using carbonate tape. A single measurement of the percentage content of elements in the analysed human and canine material was conducted each time at a $0.5 \mu \mathrm{m} \times 0.5 \mu \mathrm{m}$ point. The result was the mean of seven measurements conducted at randomly selected points on the surface of the analysed material. In this way we determined the percentage content of various elements on the surface of a given fragment of fascial tissue. The content of each element was displayed as weight percentage (wt.\%). Additionally, we mapped the elements on the surface of the specimens, each time starting by taking the priming image using a secondary electron detector (SE1). All the examinations were conducted under high vacuum conditions with accelerating voltage of $20 \mathrm{kV}$. The mapping of particular elements is presented on maps (Fig. 3, Fig. 4).

The statistical analysis was performed with the use of StatSoft Statistica 8.0 software. First, the obtained data were processed in order to detect and eliminate outlying measurements (Grubbs test). In our statistical calculations we assumed the independence of measurements of elemental composition and the standard value of confidence level $\alpha=0.05$ for hypothesis testing. Note that according to standard normality test results (Kolmogorov-Smirnov and Shapiro-Wilk test) the analysed measurements were not distributed normally. Hence, nonparametric tests were use to find out statistically significant differences among the compared specimens.

A nonparametric version of the one-factor analysis of variance in the form of the Kruskal-Wallis test was used for measurements of the content of particular elements in fascia for various individuals. This test enables evaluation of the hypothesis on origination of the specimens from the same population (testing of median equality for particular specimens). In turn, the non-parametric MannWhitney $U$ test was applied to test if two independent specimensoriginated from the same population.

\section{RESULTS}

The analyses of elemental composition conducted on the surfaces of the examined fragments of human and canine fascial tissues demonstrated the presence of the following micro and macro elements: $\mathrm{C}, \mathrm{O}, \mathrm{N}, \mathrm{Na}, \mathrm{Mg}$, 
Table 1. Median, mean, and standard deviation comparison of the percentage content of selected elements and testing probability using the $U$ Mann-Whitney test.

\begin{tabular}{|c|c|c|c|c|c|c|c|}
\hline & Human & & & Dog & & & $U \mathrm{M}-\mathrm{W}$ \\
\hline Element & $\begin{array}{l}\text { Median } \\
\text { (wt.\%) }\end{array}$ & $\begin{array}{l}\text { Mean } \\
\text { (wt.\%) }\end{array}$ & S.D. & $\begin{array}{l}\text { Median } \\
\text { (wt.\%) }\end{array}$ & $\begin{array}{l}\text { Mean } \\
\text { (wt.\%) }\end{array}$ & S.D. & $p$ \\
\hline C & 40.78 & 41.305 & 6.637 & 43.86 & 44.851 & 7.854 & 0.0028 \\
\hline $\mathrm{N}$ & 19.03 & 18.732 & 3.627 & 17.95 & 17.805 & 5.886 & 0.3813 \\
\hline $\mathrm{O}$ & 33.69 & 33.553 & 4.878 & 31.14 & 31.876 & 4.907 & 0.0100 \\
\hline $\mathrm{Na}$ & 1.80 & 1.933 & 0.944 & 1.15 & 1.246 & 0.605 & 0.0000 \\
\hline $\mathrm{Mg}$ & 0.79 & 0.769 & 0.369 & 0.41 & 0.422 & 0.206 & 0.0000 \\
\hline $\mathrm{Al}$ & 0.67 & 0.694 & 0.387 & 0.32 & 0.337 & 0.234 & 0.0000 \\
\hline $\mathrm{Si}$ & 0.35 & 0.453 & 0.363 & 0.16 & 0.173 & 0.050 & 0.0000 \\
\hline$P$ & 0.45 & 0.586 & 0.381 & 0.26 & 0.405 & 0.370 & 0.0000 \\
\hline$S$ & 0.48 & 0.475 & 0.148 & 0.31 & 0.308 & 0.104 & 0.0000 \\
\hline $\mathrm{Cl}$ & 0.04 & 0.047 & 0.024 & 0.03 & 0.028 & 0.015 & 0.0000 \\
\hline $\mathrm{K}$ & 0.02 & 0.026 & 0.014 & 0.03 & 0.035 & 0.020 & 0.0017 \\
\hline $\mathrm{Ca}$ & 0.09 & 0.150 & 0.145 & 0.06 & 0.086 & 0.069 & 0.0001 \\
\hline $\mathrm{Ti}$ & 0.06 & 0.061 & 0.023 & 0.04 & 0.040 & 0.012 & 0.0000 \\
\hline $\mathrm{Fe}$ & 0.12 & 0.136 & 0.081 & 0.08 & 0.078 & 0.032 & 0.0000 \\
\hline Co & 0.08 & 0.092 & 0.055 & 0.05 & 0.052 & 0.032 & 0.0001 \\
\hline $\mathrm{Ni}$ & 0.13 & 0.163 & 0.126 & 0.06 & 0.078 & 0.056 & 0.0000 \\
\hline $\mathrm{Cu}$ & 0.22 & 0.279 & 0.219 & 0.08 & 0.102 & 0.085 & 0.0000 \\
\hline $\mathrm{Zn}$ & 0.27 & 0.431 & 0.400 & 0.10 & 0.131 & 0.090 & 0.0000 \\
\hline
\end{tabular}

Al, P, S, Si, Zn, Cu, Ni, Ca, Fe, Co, Ti, Cl, and K. The obtained measurement results of the percentage content of these elements in canine and human fascia lata were processed statistically and are shown in Table 1.

Since the normality assumptions for the measurements are significantly violated, the non-parametric $U$ MannWhitney test for assessing two independent population medians is applied. The evaluated null hypothesis is as follows: "For each element, the median of human percentage content equals the median of canine percentage content". The assumed significance level is $\alpha=0.05$ (if testing probability $p>\alpha$, then null hypothesis is accepted, otherwise it is rejected).

The elements observed in both species in the highest concentration included $\mathrm{C}, \mathrm{O}$, and $\mathrm{N}$. The next highest

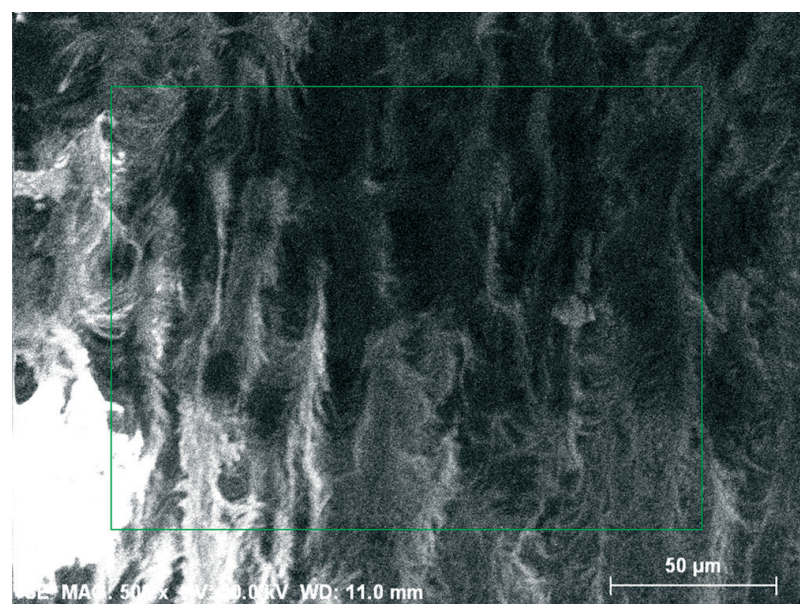

Figure 2. Image capture window with a map area for a specimen of canine fascia lata. percentage contributions were noted for $\mathrm{Na}, \mathrm{Mg}, \mathrm{Al}, \mathrm{P}$, and $\mathrm{S}$, while $\mathrm{K}, \mathrm{Cl}$, and, Ti were noted at the limit of the apparatus detection capability.

In the case of the three elements whose contribution to the composition of fascia is the highest (carbon, oxygen, and nitrogen), the differences between dogs and humans are statistically significant except for N. However, in the case of the remaining detected elements, the differences between the dog and human tissue were statistically significant (testing probability obtained from the applied tests $p<<\alpha$ ). It can be noticed that the average content of those elements is in most cases higher for human than canine fascia.

We also mapped various elements on the surfaces of the analysed canine and human specimens (Fig. 2).

With respect to $\mathrm{C}, \mathrm{O}$, and $\mathrm{N}$ (Fig. 3), we found a regular band like distribution of the elements, while the arrangement of other elements was more chaotic (Fig. 4).

\section{DISCUSSION}

The fascial system of the body is an integral element of the musculoskeletal system. It is responsible for the structural integrity of the organism, ensuring its strength and the ability to react efficiently to external and internal mechanical stimuli. Disorders of the fascial system are classified under rheumatic diseases of the soft tissue. They are characterised by pain of varying intensity, considerable movement restriction, and significant discomfort for the patient. In many cases a standard physical examination cannot detect fascia disorders because often the only symptoms are discomfort and pain subjectively perceived by the patient (Kroening et al., 1985; Joshua, 2007; Stecco et al., 2009).

Our analysis of scientific papers indicates that only during the last decade has the fascial apparatus of humans and animals received considerable attention (Michel et al., 1984; Schnabel et al., 1994; Findley, 2009; Stecco et al., 2009).

Fascia, similar to skin, is the first line of defence against undesirable mechanical, chemical, and biological stimuli. The connective tissue forming fascia is made mostly of collagen fibres and, to a smaller degree, of elastic fibres. The high collagen content ensures its

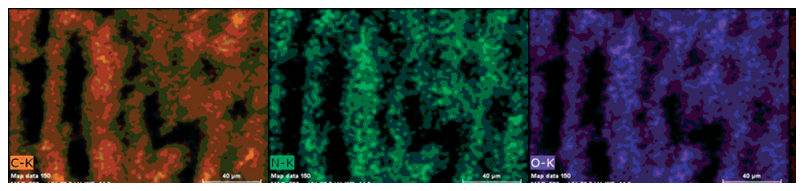

Figure 3. Topography of selected elements (C, N, and O) on the surface of a canine fascia lata specimen presented as a map.

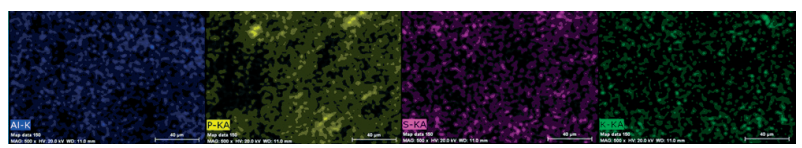

Figure 4. Topography of selected elements (AI, P, S, and K) on the surface of a canine fascia lata specimen presented as a map. 
strength and flexibility. The collagen fibres are arranged in the fascia in a spatial network the cellular elements are suspended.

The ultrastructural features are essential for the proper functioning of a given tissue, but of equal importance is the elemental composition. Although in recent years there has been a slight increase in interest in the elemental composition of various tissues and organs, this topic definitely has numerous areas where our knowledge remains incomplete (Brown, 1926; Lenglet et al., 1984; Demajo et al., 2006; Guidotti et al., 2008). It seems that in certain situations the determination of tissue elemental composition could be more reliable and informative than determination of tissue density or even it histological structure.

The determination of the spectrum of trace elements in the body fluids and tissues is connected, among others, with the determination of exposure of an individual to a particular element. It also shows individual predispositions for the accumulation of a particular mineral in a given location due to, for example, absorption from various internal and external sources, metabolic diseases $(\mathrm{Cu}$ accumulation), and impaired excretion ( $\mathrm{Pb}$ accumulation). An assessment of the elemental composition of the serum and whole blood, while readily available, is also of limited usefulness mainly due to the fact that the serum content of particular elements results from the action of numerous homeostatic and compensatory mechanisms in the body, and only to a some degree reflects the actual mineral status of the rest of the tissues and organs (Cornelis et al., 1995; Massadeh et al., 2010). Other tissues, such as parenchymal organs or fascia, may provide more relevant information on the elemental status of human and animal bodies.

The basic morphological, functional, and biochemical parameters of the fascial system have still not been established unequivocally. Knowledge of the elemental composition will allow us to better understand both the anatomical structure and the function of this type of connective tissue. The bulk elemental composition of the whole fascia is determined to a high degree by the amino acid composition of collagen, i.e., glycine (33.5\%), proline $(12 \%)$, and hydroxyproline $(10 \%)$ (Widdowson et al., 1995). The regular arrangement of the three dominant elements $\mathrm{C}, \mathrm{O}$, and $\mathrm{N}$ on the surface, seen in the mapping of the analysed specimens, was due to the fact that the analysed tissue was composed mainly of collagen fibres (Kumai et al., 2006). Most of the elements in the fascia may also be cofactors of enzymes contributing to fascial collagen metabolism, as in the case of zinc and lysine oxidase (Wirtschafter et al., 1962; Rosch et al., 2002; Szczęsny et al., 2005).

In future it would be interesting to compare the elemental composition of pathologically unchanged fascia with the corresponding tissue from individuals suffering from myofascial disorders (Michel et al., 1984; Schnabel et al., 1994).

Despite two mammalian species analysed here, dog and human, being fairy closely related evolutionary and living virtually in the same environment, the results of this study demonstrated substantially lower concentration of most elements in the canine tissue compared to the human one. An opposite phenomenon seems to obey in the case of serum minerals levels (Kabata et al., 2005; Winnicka, 2008). Taking into the consideration differences in the elemental content of other tissues, e.g. the liver content of $\mathrm{Zn}, \mathrm{Cu}$, and $\mathrm{Fe}$ it is also higher in the case of dogs compared to human beings (Brown, 1926; Bush, 1995; Schultheiss et al., 2002).

\section{REFERENCES}

Bang RL, Al-Bader AL, Sharma PN, Mattapallil AB, Behbehani AI, Dashti H (2002) Trace elements content in serum, normal skin, and scar tissues of keloid and normal scar patients. J Trace Elem Exp Med 15: 57-66.

Becker RO, Spadaro JA, Berg EW (1968) The Trace Elements of Human Bone. J Bone Joint Surg Am 50: 326-334.

Brown H (1926) The mineral content of human, dog, and rabbit skin. J Biol Chem 68: 729-736.

Bush VJ, Moyer TP, Batts KP, Parisi JE (1995) Essential and toxic element concentrations in fresh and formalin-fixed human autopsy tissues. Clin Chem 41: 284-294.

Byrne AR, Kučera J (1989) Determination of trace elements in a human serum reference material by inductively coupled plasma mass spectrometry. MCA 99: 373-379.

Chaudhry H, Huang CY, Schleip R, Ji Z, Bukiet B, Findley T (2007) Viscoelastic behavior of human fasciae under extension in manual therapy. J Bodyw Mov Ther 11: 159-167.

Cornelis R, Heinzow B, Herber RFM, Christensen MJ, Paulsen M, Sabbion E, Templeton DM, Thomassen Y, Vahter M (1995) Vesterberg sample collection guidelines for trace elements in blood and urine. Pure \& Appl Chem 67: 1575-1608.

Czogała J, Teper E, Czogała K (2006) Canine urolithiasis-modern diagnostic techniques. Życie Wet 81: 678-682 (in Polish).

Demajo M, Jozanov-Stankov O, Đujić I (2006) Content of microelements in the rat pineal gland at different ages and the effects of selenium supplementation. Arch Biol Sci 58: 69-75.

Findley T (2009) Int J Ther Massage Bodywork: Research, Education, \& Practice, Vol 2, No 3.

Guidotti TL, McNamara J, Moses MS (2008) The interpretation of trace element analysis in body fluids. Indian J Med Res 128: 524-532.

Joshua L (2007) Effects of trigger point pressure release on pain modulation and associated movement impairments in a patient with severe acute myofascial pain syndrome: a case report. The Pain Clinic 19: $83-87$.

Kabata J, Kalinowski L, Szczepańska-Konkel M, Angielski S (2005) Laboratory tests in everyday Practice. MAKmed Gdansk.

Kahler GA, Fisher FM, Sass RL (1976) The chemical composition and mechanical properties of the hinge ligament in bivalve mollusks. Biol Bull 151: 161-181.

Kaliński K, Marycz K, Czogała J, Wojciechowicz E (2009) Elemental composition of the skin in the course of canine atopic dermatitis. Zesz Nak UP Wroc 575: 43-55.

Koźma EM, Olczyk K, Głowacki A (2001) Dermatan sulfates of normal and scarred fascia. Comp Biochem Physiol Part B 128: 221-232.

Krachler M, Rossipal E, Irgolic KJ (1998) Trace elements in formulas based on cow and soy milk and in Austrian cow milk determined by inductively coupled plasma mass spectrometry. Biol Trace Elem Res 65: 53-74.

Kroening FJ, Dennis RH, Siegert R (1985) Myofascial pain syndrome of the head and neck: a review of clinical characteristics of $164 \mathrm{pa}$ tients. Oral Surg, Oral Med and Oral Path 60: 615-623.

Kumai T, Yamada G, Takakura Y, Tohno Y, Benjamin M (2006) Trace elements in human tendons and ligaments. Biol Trace Elem Res 114: 151-161.

Larsen RD, Takagishi N, Posch JL (1960) The pathogenesis of dupuytren's contracture: experimental and further clinical observations. J Bone Joint Surg Am 42: 993-1007.

Lenglet WJ, Bos AJ, Stap CC, Vis RD, Delhez H, Hamer CJ (1984) Discrepancies between histological and physical methods for trace element mapping in the rat brain. Histochem Cell Biol 81: 305-309.

Massadeh A, Gharibeh A, Omari K, Al-Momani I, Alomari A, Tumah $\mathrm{H}$, Hayajneh W (2010) Simultaneous determination of $\mathrm{Cd}, \mathrm{Pb}, \mathrm{Cu}$, $\mathrm{Zn}$, and Se in human blood of Jordanian smokers by ICP-OES. Biol Trace Elem Res 133: 1-11.

Michel R, Hofmannl J, Lder F, Zilkens J (1984) Trace element burdening of human tissues due to the corrosion of hip-joint prostheses made of cobalt-chromium alloys. Arch Orthop Trauma Surg 103: 85-95.

Olszytńska-Janus S, Szymborska K, Komorowska M, Lipiński J (2008) Usefulness of spectroscopy for biomedical engineering. Acta Bioeng Biomech 10: 45-49.

Olsztyńska-Janus S, Szymborska-Małek K, Gąsior-Głogowska M, Walski T, Komorowska M, Witkiewicz W, Pezowicz C, Kobielarz M, Szotek S (2012) Spectroscopic techniques in the study of human tissues and their components. Part I:IR spectroscopy. Acta Bioeng Biomech 14: 101-115.

Robertson JD (1961) Studies on the chemical composition of muscle tissue I. The muscles of the Hagfish Myxine Glutinosa L and the Roman eel Muraena Helena L. J Exp Biol 37: 879-888.

Robertson JD (1961) Studies on the chemical composition of muscle tissue II. The abdominal flexor muscles of the Lobster Nephrops Norvegicus. J Exp Biol 38: 707-728 
Rosch R, Klinge U, Si Z, Junge K, Klosterhalfen B, Schumpelick V (2002) A role for the collagen I/III and MMP-1/-13 genes in primary inguinal hernia? BMC Med Genet 3: 1-6.

Sahin M, Karademir M, Özer S, Avsar FM, Yol S, Çaglayan O, Aktan M (2001) The effects of different suture techniques on wound healing in abdominal wall closure turk. J Med Sci 31: 391-394.

Samborski W (2006) Fibromialgia in general practice. Med Rodz 9: 2-6 (in Polish).

Schnabel C, Herpers U, Michel R, Loer F, Buchhorn G, Willert HG (1994) Changes of concentrations of the elements Co, Cr, Sb, and Sc in tissues of persons with joint implants. Biol Trace Elem Res 43 389-395.

Schultheiss PC, Bedwell CL, Hamar DW, Fettman MJ (2002) Canine liver iron, copper, and zinc concentrations and association with histologic lesions. I Vet Diagn Investig Official Publication of the American Association of Veterinary Laboratory Diagnosticians Inc 14: 396-402.

Stecco C, Pavan PG, Porzionato A, Lancerotto L, Macchi V, Natal AN, De Caro R (2009) Mechanics of crural fascia from anatomy to constitutive modelling. Surg Radiol Anat 31: 523-529.
Stecco L, Stecco C (2009) Fascial Manipulation: Practical part. Piccin, Italy. Sun WD, Zhang KC, Wanga JY, Wang XL (2010) The chemical composition and ultrastructure of uroliths in Boer goats. Vet $J$ 186: $70-75$

Szczęsny W, Dąbrowiecki S (2005) Contemporary opinions on the etiopathogenesis of abdominal wall hernias. Chir Pol 7: 280-286.

Tengrup I, Ahonen J, Zederfeldt B (1981) Influence of zinc on synthesis and the accumulation of collagen in early granulation tissue. Surg Gynecol Obstet Mar 152: 323-326.

Vanhoe H, Vandecasteele C, Versieck J, Dams R (1989) Determination of iron, cobalt, copper, zinc, rubidium, molybdenum, and cesium in human serum by inductively coupled plasma mass spectrometry. Anal Chem 1: 1851-1857.

Widdowson EM, Dickerson JWT (1995)The effect of growth and function on the chemical composition of soft tissues. Biochem $J$ 77: $30-43$.

Winnicka A (2008) Reference ranges for basic laboratory tests in veterinary medicine. SGGW, Warszawa (in Polish).

Wirtschafter Z, Bentley J (1962) The extractable collagen of lathyrytic rats with relation to age. Lab Invest 11: 365-370. 